\title{
Incidence and Treatment of Post-meningitic Hydrocephalus in the Newborn
}

\author{
JOHN LORBER and DOUGLAS PICKERING \\ From the Department of Child Health, University of Sheffield, and the Children's Hospital, Sheffield
}

Neonatal meningitis remains an extremely difficult diagnostic and therapeutic problem. In spite of the large number of antibiotics which are now at our disposal, the mortality remains high and few survivors escape without sequelae. In recent years, however, improvements have occurred not only in the management of the acute illness, but also in the treatment of a common complication, namely hydrocephalus. This aspect is the main topic of our paper. We shall only deal with infants who were anatomically normal at birth. The much larger problem of meningitis in infants born with spina bifida cystica is outside the scope of this investigation and has been dealt with elsewhere (Lorber and Segall, 1962; Lorber and Bruce, 1963; Bruce and Lorber, 1964). Our material is derived from two sources. First, 7 infants born at the Jessop Hospital for Women, Sheffield, who developed neonatal meningitis. Secondly, 19 infants who were treated at Sheffield Children's Hospital for hydrocephalus which they had developed as a result of neonatal meningitis.

\section{Incidence of Neonatal Meningitis}

The incidence of neonatal meningitis is high, and according to Haggerty and Ziai (1964) it is higher than at any other comparable age-group. Groover, Sutherland, and Landing (1961) in a prospective survey found its incidence to be $0 \cdot 4 / 1,000$ in 43,400 live births. This figure is in good agreement with our own data from the Jessop Hospital for Women, Sheffield. During the 6 years, 1958-63 inclusive, 13,295 infants were born and 7 of these were known to have developed meningitis, excluding those born with spina bifida cystica. This figure corresponds to approximately $0 \cdot 5 / 1,000$.

In spite of its high incidence, it is apparent that no single unit is likely to have sufficient new cases in a reasonable period of time to allow prospectively planned, controlled, therapeutic trials. It would be wrong, for this reason, to be dogmatic about optimal

Received May 3, 1965. treatment, including the choice of drugs and their routes of administration. Of our 7 patients from the Jessop Hospital, only 2 died and 2, including one who died later, developed clinically apparent postmeningitic hydrocephalus. The diagnosis was established on the day the symptoms started in all those 5 who eventually did well. The details of these 7 infants are shown in Table I.

\section{Incidence of Post-meningitic Hydrocephalus}

Four of the 16 survivors reported by Watson (1957), 1 out of 9 by Dyggve (1962), 8 out of 19 by Yu and Grauaug (1963), and 2 out of 5 reported by Bush (1964) were recognized as having hydrocephalus. In our own experience at the Jessop Hospital 2 out of 6 survivors developed hydrocephalus. In Table II we show the collected incidence of recognized hydrocephalus among the survivors, namely $31 \%$ of 55 cases. It would be remarkable if the true incidence were not higher, bearing in mind that hydrocephalus of lesser degree is often present with normal head circumference and may not be clinically progressive, as can be readily shown in infants born with meningomyelocele (Lorber, 1961). In all our patients the hydrocephalus was of severe degree.

\section{Infants with Post-meningitic Hydrocephalus}

The main part of this paper deals with 19 infants who developed hydrocephalus as a result of neonatal meningitis. These were either treated by us from the beginning (4), or were referred from other units for the treatment of post-meningitic hydrocephalus (15). There were 15 boys and only 4 girls. The ages of the 15 infants referred to us after they had been treated for their meningitis elsewhere varied between 4 and 19 weeks.

Only 7 of the 15 infants who were referred for treatment of their post-meningitic hydrocephalus could be considered to have recovered from their 
Incidence and Treatment of Post-meningitic Hydrocephalus in the Newborn

TABLE I

Cases of Neonatal Meningitis: Jessop Hospital for Women, 1958-1963

\begin{tabular}{|c|c|c|c|c|c|c|c|c|c|c|}
\hline \multirow{2}{*}{$\begin{array}{l}\text { Case } \\
\text { No. }\end{array}$} & \multirow{2}{*}{$\begin{array}{l}\text { Birth } \\
\text { Weight } \\
\text { (lb.) }\end{array}$} & \multirow{2}{*}{$\begin{array}{l}\text { Presenting } \\
\text { Symptom }\end{array}$} & \multirow{2}{*}{$\begin{array}{c}\text { Day } \\
\text { of } \\
\text { Onset }\end{array}$} & \multirow{2}{*}{$\begin{array}{l}\text { Day } \\
\text { of } \\
\text { Diag- } \\
\text { nosis }\end{array}$} & \multirow{2}{*}{ Organism } & \multicolumn{3}{|c|}{ Treatment } & \multicolumn{2}{|c|}{ Follow-up } \\
\hline & & & & & & Oral & Intramuscular & Intrathecal & Age & Result \\
\hline 1 & $3 \cdot 8$ & Drowsiness & 5 & 5 & Listeria & $\begin{array}{l}\text { Chlor- } \\
\text { amphenicol }\end{array}$ & Penicillin & 一 & 44 wk. & Normal \\
\hline 2 & $7 \cdot 4$ & $\begin{array}{l}\text { Grunting } \\
\text { respiration }\end{array}$ & 4 & 4 & Proteus & Tetracycline & $\begin{array}{l}\text { Chlor- } \\
\text { amphenicol }\end{array}$ & $\begin{array}{l}\text { Streptomycin, } \\
\text { hydro- } \\
\text { cortisone }\end{array}$ & $18 \mathrm{mth}$. & Normal \\
\hline 3 & $6 \cdot 4$ & Irritability & 1 & 1 & Esch. coli & $\begin{array}{l}\text { Sulphadim- } \\
\text { idine }\end{array}$ & $\begin{array}{l}\text { Tetracycline, } \\
\text { chloram- } \\
\text { phenicol, }\end{array}$ & $\begin{array}{l}\text { cortisone } \\
\text { Penicillin, } \\
\text { streptomycin, } \\
\text { hydrocor- }\end{array}$ & $2 \mathrm{yr}$. & Normal \\
\hline 4 & $7 \cdot 1$ & Limpness & 1 & 1 & 'Sterile' & Tetracycline & $\begin{array}{l}\text { streptomycin } \\
\text { Penicillin, } \\
\text { streptomycin }\end{array}$ & tisone & $2 \mathrm{yr}$. & Normal \\
\hline 5 & $5 \cdot 8$ & Collapse & 15 & 15 & Listeria & $\begin{array}{l}\text { Cortisone, } \\
\text { chloram- } \\
\text { phenicol, } \\
\text { sulphadim- } \\
\text { idine }\end{array}$ & $\begin{array}{l}\text { Streptomycin, } \\
\text { penicillin }\end{array}$ & $\begin{array}{l}\text { Chloramphen- } \\
\text { icol, hydro- } \\
\text { cortisone }\end{array}$ & $5 \mathrm{yr}$. & $\begin{array}{c}\text { Normal } \\
\text { (with } \\
\text { valve) }\end{array}$ \\
\hline 6 & $7 \cdot 6$ & $\begin{array}{l}\text { Resp. distress } \\
\text { /Fits }\end{array}$ & 2 & 14 & $\begin{array}{l}\text { Staph. } \\
\quad \text { aureus }\end{array}$ & - & $\begin{array}{l}\text { Methicillin, } \\
\text { chloram- } \\
\text { phenicol }\end{array}$ & $\begin{array}{c}\text { Chloram- } \\
\text { phenicol, } \\
\text { hydro- }\end{array}$ & $11 \mathrm{mth}$. & $\begin{array}{c}\text { Amentia } \\
\text { spastic, } \\
\text { fits; }\end{array}$ \\
\hline 7 & $3 \cdot 1$ & Resp. distress & 1 & $\begin{array}{c}\text { At } \\
\text { ne- } \\
\text { cropsy }\end{array}$ & $\begin{array}{l}\text { B-haem. } \\
\text { strep. }\end{array}$ & 一 & Erythromycin & - & $1 \mathrm{wk}$. & Died \\
\hline
\end{tabular}

meningitis at the time they were transferred to us. In these 7 both the lumbar and the ventricular CSF was sterile, and was either normal with regard to cell count, protein, and sugar content, or there was only slight deviation in these respects. In four others the CSF from the lumbar theca and the lateral ventricle was sterile, but there was still gross excess of protein $(140-600 \mathrm{mg} . / 100 \mathrm{ml}$.) and the cell count was raised to $36-486 / \mathrm{c} . \mathrm{mm}$. In these children further antibiotic treatment was given before investigating and treating the hydrocephalus. Finally, 4 infants, referred as cases of post-meningitic hydrocephalus, still had gross pyogenic ventriculitis. Culture of their CSF grew Esch. coli (3 cases) and Bacillus proteus respectively. During the same period 2 other infants were referred as cases of postmeningitic hydrocephalus, but both had gross active ventriculitis from which they died. The reason for such a mistake in diagnosis lay in the fact that before transfer to our hospital, their ventricular CSF was not examined. These last 2 are not included in our series. The ages of the children who were admitted to us direct with active, previously untreated, meningitis varied between 6 days and 4 weeks of age, but one of these infants already had had much antibiotic treatment by many drugs for a staphylococcal septicaemia and multiple abcesses. In this infant the meningitis was a relatively unimportant part of the clinical illness, and it is not surprising that she eventually died.

We are not here concerned with the antibiotic treatment of the active meningitis. Suffice it to say, that it was appropriate to the sensitivity pattern of
TABLE II

Incidence of Clinically Recognized Hydrocephalus among Survivors of Neonatal Meningitis

\begin{tabular}{|c|c|c|c|}
\hline Authors & Year & $\begin{array}{l}\text { No. of } \\
\text { Survivors }\end{array}$ & $\begin{array}{l}\text { No. with } \\
\text { Hydro- } \\
\text { cephalus }\end{array}$ \\
\hline $\begin{array}{lll}\text { Watson } & \ldots & \ldots \\
\text { Dyggve } & \ldots & \ldots \\
\text { Bush . } & \ldots & \ldots \\
\text { Yu and Grauaug } \\
\text { Present series } \\
\text { (Jessop Hospital) }\end{array}$ & $\begin{array}{l}1957 \\
1962 \\
1964 \\
1963 \\
1965\end{array}$ & $\begin{array}{r}16 \\
9 \\
5 \\
19 \\
6\end{array}$ & $\begin{array}{l}4 \\
1 \\
2 \\
8 \\
2\end{array}$ \\
\hline Total $\ldots \quad \ldots \quad \ldots$ & 一 & 55 & $17\left(31^{\circ}\right.$ \\
\hline
\end{tabular}

the causative organism. Many infants were given antibiotics direct into the lateral ventricles, often for prolonged periods.

Bacteriology. Table III shows the causative organisms in our 19 cases. As is seen, 9 were due

TABLE III

Neonatal Meningitis Followed by Hydrocephalus: Causative Organisms

\begin{tabular}{|c|c|c|c|c|c|}
\hline \multicolumn{5}{|c|}{ Organism } & \multirow[b]{2}{*}{$\begin{array}{c}\text { No. } \\
9 \\
2 \\
2 \\
1 \\
1 \\
1 \\
1 \\
2\end{array}$} \\
\hline $\begin{array}{l}\text { Esch. coli } \\
\text { Proteus } \\
\text { Meningococcus } \\
\text { Haemophilus inf } \\
\text { Staphylococcus } \\
\text { Staphylococcus } \\
\text { Pneumococcus } \\
\text { Listeria.. }\end{array}$ & $\begin{array}{ll}\ldots & \ldots \\
\text { fluenzae } \\
\text { aureus } \\
\text { albus } \\
\ldots & \ldots \\
\ldots & \ldots\end{array}$ & $\begin{array}{l}\cdots \\
\cdots \\
\cdots \\
\cdots \\
\cdots \\
\cdots\end{array}$ & $\begin{array}{l}\cdots \\
\cdots \\
\cdots \\
\cdots \\
\cdots \\
\cdots\end{array}$ & $\begin{array}{l}\cdots \\
\cdots \\
\cdots \\
\cdots \\
\cdots \\
\cdots\end{array}$ & \\
\hline Total & . & $\ldots$ & . & . & 19 \\
\hline
\end{tabular}


to Esch. coli infection, 2 each had Listeria monocytogenes, proteus, and meningococcal infections, and one each was due to Staphylococcus albus, Staphylococcus aureus, Pneumococcus, and Haemophilus influenzae.

After recovery from their meningitis, we had to wait long enough to make sure that there was no smouldering activity which could be stirred up by operation. The CSF was repeatedly examined before ventriculography or operation. Even so, in only 2 infants was the ventricular CSF fully normal before operation. In all but 3, however, the residual abnormality was of slight degree, with a protein content of $100 \mathrm{mg} . / 100 \mathrm{ml}$. or less and a cell count of $31 / \mathrm{c} . \mathrm{mm}$. or less. There were 4 infants, however, whose CSF protein was $195,400,600$, and $600 \mathrm{mg}$. $/ 100 \mathrm{ml}$., respectively, and whose CSF cell count was between 20 and $52 /$ c.mm. In view of the rapid progress of the hydrocephalus, longer delay before operation was thought inadvisable. All these 4 did very badly.

Pneumoencephalography and ventriculography. Air studies were undertaken in all but one infant before considering ventriculo-caval shunt operation. The only infant in whom this was not done had a rapidly progressive enlargement of his head, and on ventricular puncture the cerebral mantle was less than $1 \mathrm{~cm}$. in depth. In all the others, the pneumoencephalogram or ventriculogram showed an extreme degree of ventricular dilatation (Grade 3 in our classification (Lorber, 1961)). Apart from extreme ventricular dilatation, multiple diverticula in the frontal lobes were demonstrated in 6 infants, resulting from previous ventricular punctures (Fig. 1) (Lorber and Grainger, 1963). Most others, who did not show this feature, had such a narrow cerebral rim of tissue that such cavities either could not have been accommodated, or could not be readily demonstrated radiologically. Further, multiple obstruction to the flow of CSF was demonstrated in many infants, and in 6 of these there was no communication between the two lateral ventricles. This finding was confirmed by failure of dye to pass from one ventricle to the other. In at least one infant (with Bacillus proteus meningitis) there were multiple loculi which precluded any possibility of surgical treatment. He was the only infant of the 19 who was not operated on. $\mathrm{He}$ became profoundly retarded and had frequent convulsions until he died some two years later.

In every instance the communication between the lumbar theca and the cerebral ventricles was also tested by air and dye studies. In 6 there was no communication. This fact, however, did not influence the decision for surgical treatment, or its technique, as ventriculo-caval shunts do not depend on this factor.

Head circumference. The head circumference of all infants was in excess of the 90th percentile at the last measurement before operation, in spite of the fact that excessive rise of intracranial tension was prevented by frequent ventricular punctures either during the treatment of the meningitis or the subsequent period of observation. The infant with the

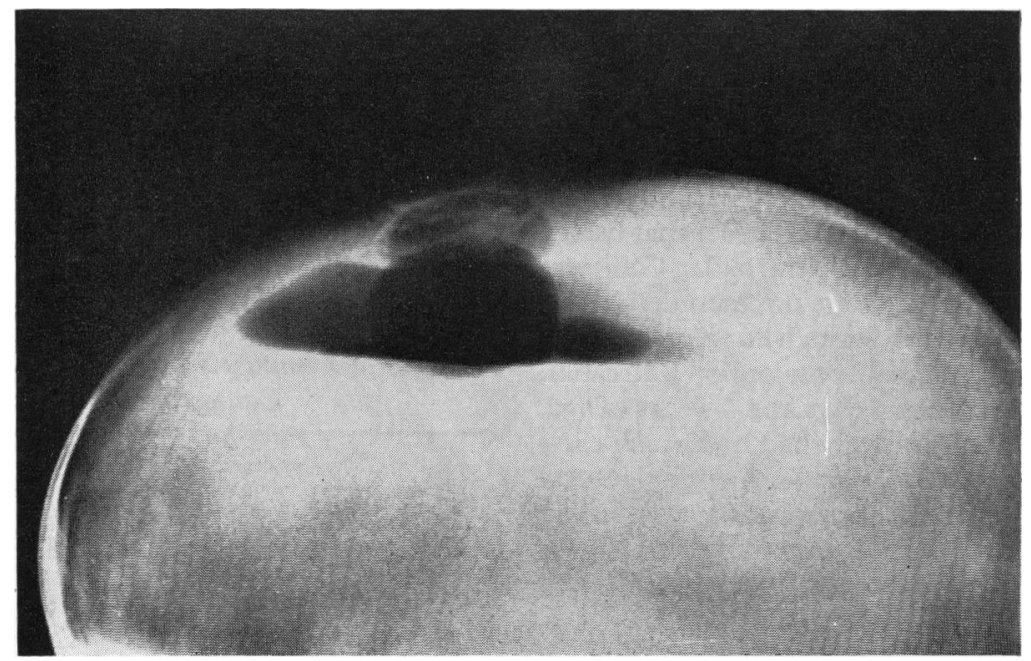

FIG. 1.-(S.D., Table V). Ventriculogram in a baby showing extreme hydrocephalus as well as multiple diverticula in the frontal lobes. 


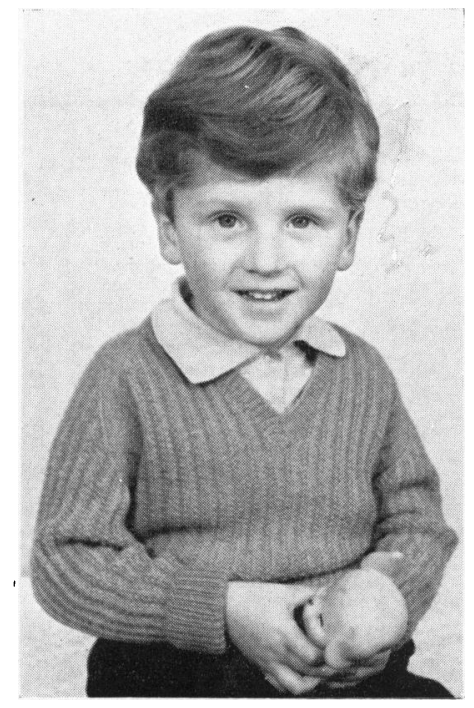

FIG. 2.-Same child as Fig. 1 at 4 years of age.

greatest head circumference, $21 \cdot 25$ in. $(54 \mathrm{~cm}$.) at $4 \frac{1}{2}$ months of age, did very well and had no physical or mental sequelae when last seen at 4 years of age (Fig. 2).

Neurological condition before operation. One infant had spastic hemiplegia and 5 had spastic paraplegia. The fundi, however, were normal on ophthalmoscopic examination in all those examined (10 cases). At this young age and after a prolonged illness, it would be unwise to comment on the mental development, on hearing, and on eyesight, but blindness and mental retardation was suspected in several cases.

Operative treatment. All operative treatment was carried out by Mr. R. B. Zachary and his surgical staff and consisted of the insertion of a Holter valve in all 18 infants who were operated on. In 2 infants, however, who had communicating hydrocephalus, a theca-peritoneal shunt was first performed, but this did not arrest the hydrocephalus.

The age at which the ventriculo-caval shunt was performed varied between 2 and 7 months of age. There was no operative mortality and all infants were discharged home. The operation achieved its primary immediate objective of reducing increased intracranial tension, as judged by the head circumference measurement and the tension of the anterior fontanelle in all but one infant: this last infant had the highest CSF protein in the ventricular CSF
(600 mg./100 ml.), and his head circumference continued to increase at an undue rate. He was admitted to another hospital later, this time with a Haemophilus influenzae meningitis, of which he died at the age of 5 months. The causative organism in his first episode of meningitis was Esch. coli.

In 3 children a $T$-tube was used and separate catheters were placed into both lateral ventricles to deal with the problem of absence of communication between the two sides. In another similar situation a hole was made in the midline structures of the brain to establish communication between the two sides.

Further operative procedures had to be undertaken because of blockage of the shunt in 8 infants, who between them had 12 further operations to relieve obstruction either of the ventricular catheter (2) or in the jugular vein (10).

Further, infection round the valve necessitated removal of the whole shunt in 3 children. One, at 1 year of age, apparently no longer required the shunt: he made good progress and was a normal boy at 3 years of age. The second child became grossly retarded with a head circumference of 24 in. $(61 \mathrm{~cm}$.). The third child who had her shunt removed was a profoundly retarded infant who died a year later. It is possible that the shunting system is now redundant in some children, but as it gives rise to no trouble, it is considered unwise to interfere with it.

\section{Results of Treatment in 19 Cases of Post-meningitic Hydrocephalus}

Children who died. Of the 19 children with post-meningitic hydrocephalus, 5 died, including the one infant with proteus meningitis who was not operated on, 3 infants who had Esch. coli meningitis, and one who had staphylococcal septicaemia with liver and bone abscesses and in whom the meningitis was only one feature of his illness.

All 5 who died had multiple blocks within the CSF pathways. One had the highest CSF protein in the series and developed a fresh acute haemophilus meningitis. Further, the delay between the first symptoms suggestive of meningitis and its diagnosis was the longest in 4 of the 5 infants, while the fifth developed her meningitis at 2 days of age.

Only one of the infants died in our hospital. Necropsy was not performed, and neither do we have detailed necropsy reports about the others who died elsewhere.

Children who survived with mental and neurological handicaps (Table IV). Of the 14 survivors, 7 were left with considerable mental or 
TABLE IV

Post-meningitic Hydrocephalus: 7 Children Who Survived with Sequelae

\begin{tabular}{|c|c|c|c|c|c|c|c|c|c|c|c|}
\hline \multirow{2}{*}{\multicolumn{2}{|c|}{$\begin{array}{l}\text { Case No. } \\
\text { and Initials }\end{array}$}} & \multirow{2}{*}{$\begin{array}{l}\text { Age at } \\
\text { Onset of } \\
\text { Menin- } \\
\text { gitis } \\
\text { (days) }\end{array}$} & \multirow[b]{2}{*}{ Organism } & \multicolumn{3}{|c|}{ Ventriculography } & \multirow{2}{*}{$\begin{array}{l}\text { Age at } \\
\text { Opera- } \\
\text { tion } \\
\text { (wk.) }\end{array}$} & \multicolumn{3}{|c|}{ Last Examination } & \multirow[b]{2}{*}{ Comment } \\
\hline & & & & Age & $\begin{array}{c}\text { CSF } \\
\text { Pressure }\end{array}$ & $\begin{array}{l}\text { Grade } \\
\text { of }\end{array}$ & & Age & Circum- & Handicap & \\
\hline $\begin{array}{l}1 \\
2 \\
3\end{array}$ & $\begin{array}{l}\text { B.S. } \\
\text { M.J. } \\
\text { J.H. }\end{array}$ & $\begin{array}{l}9 \\
4 \\
6\end{array}$ & $\begin{array}{l}\text { Esch. coli } \\
\text { Esch. coli } \\
\text { Esch. coli }\end{array}$ & $\begin{array}{l}15 \\
10 \\
24\end{array}$ & $\begin{array}{l}280 \\
400+ \\
200\end{array}$ & $\begin{array}{l}3 \\
3 \\
3\end{array}$ & $\begin{array}{l}16 \\
11 \\
27\end{array}$ & $\begin{array}{l}2 \frac{1}{2} \\
1 \\
1\end{array}$ & $\begin{array}{l}51 \\
47 \\
47 \cdot 6\end{array}$ & \multirow{4}{*}{$\begin{array}{l}\text { Extremely retarded; fits } \\
\text { Retarded; visual defect } \\
\text { Moderately retarded; } \\
\text { physically normal } \\
\text { Grossly retarded; blind } \\
\text { Grossly retarded; } \\
\text { spastic; fits; IQ } 44 \\
\text { Poor vision } \\
\text { Grossly retarded; } \\
\text { spastic; blind }\end{array}$} & 1 Revision \\
\hline $\begin{array}{l}4 \\
5\end{array}$ & $\begin{array}{l}\text { M.T. } \\
\text { P.B. }\end{array}$ & $\begin{array}{r}24 \\
9\end{array}$ & $\begin{array}{l}\text { Esch. coli } \\
\text { Esch. coli }\end{array}$ & $\begin{array}{r}13 \\
8\end{array}$ & $\begin{array}{l}240 \\
190\end{array}$ & $\begin{array}{l}3 \\
3\end{array}$ & $\begin{array}{r}19 \\
9\end{array}$ & $\frac{1}{\frac{1}{2}}$ & $\begin{array}{l}48 \\
41\end{array}$ & & 1 Revision \\
\hline 6 & G.L. & 8 & Listeria & 22 & $?$ & 3 & 23 & 7 & 61 & & \multirow{2}{*}{$\begin{array}{l}\text { Shunt removed } \\
\text { after revision } \\
\text { Several } \\
\text { revisions }\end{array}$} \\
\hline 7 & R.B. & 12 & Haemophilus & 9 & 200 & 3 & 16 & 3 & 52 & & \\
\hline
\end{tabular}

neurological sequelae resulting from the meningitis and the hydrocephalus. Among these are 5 children whose infection was due to Esch. coli. Hence, of the 9 infants with Esch. coli meningitis and who developed hydrocephalus, only 1 did well.

Of the 7, 1 is moderately retarded; all the others are also retarded, often to an extreme degree, and in addition have physical handicaps of spasticity (2), blindness or visual defect (4), and convulsions (2). Several are too young to evaluate more fully; for example, it is impossible to say anything about hearing defects at this stage.

One child (G.L.), who no longer has a shunt, has a very large head with a circumference of 24 in. (61 $\mathrm{cm}$.), which is partly due to failure of the initial theca-peritoneal shunt to arrest the hydrocephalus. This occurred before the technique of ventriculocaval shunt was available. Another infant (P.B.) is microcephalic now and is very severely handicapped. The head circumference of the others is within the normal range.
Children who recovered completely (Table V). 7 infants, or one-third of all patients, made a complete recovery. These infants were slightly older at the onset of their meningitis than those who did badly. The causative organisms were also very different: Meningococcus in 2 cases, Pneumococcus, Staphylococcus albus, Listeria monocytogenes, Esch. coli and Bacillus proteus in one each. Only 2 of these were therefore caused by organisms (Esch. coli and Bacillus proteus) that are particularly difficult to counter adequately and to eradicate in reasonable time. Before operation none of these children had abnormal neurological signs other than their hydrocephalus.

There was no difference in the degree of hydrocephalus, between this group who recovered and those who farcd badly. All but one had Grade 3 hydrocephalus. There was, however, free communication between the two ventricles, and between the ventricles and the lumbar subarachnoid space in all 7 children who did well. This feature greatly

TABLE V

Post-meningitic Hydrocephalus: 7 Children Who Survived without Sequelae

\begin{tabular}{|c|c|c|c|c|c|c|c|c|c|c|}
\hline \multirow{2}{*}{\multicolumn{2}{|c|}{$\begin{array}{l}\text { Case No. } \\
\text { and Initials }\end{array}$}} & \multirow{2}{*}{$\begin{array}{c}\text { Age of } \\
\text { Onset } \\
\text { of } \\
\text { menin- } \\
\text { gitis } \\
\text { (days) }\end{array}$} & \multirow[b]{2}{*}{ Organism } & \multicolumn{3}{|c|}{ Ventriculography } & \multirow{2}{*}{$\begin{array}{c}\text { Age } \\
\text { at } \\
\text { Opera- } \\
\text { tion } \\
\text { (wk.) }\end{array}$} & \multicolumn{2}{|c|}{$\begin{array}{l}\text { Last } \\
\text { Examination }\end{array}$} & \multirow[b]{2}{*}{ Comments } \\
\hline & & & & & CSF & Graje & & $\begin{array}{l}\text { Age } \\
\text { (yr.) }\end{array}$ & $\begin{array}{l}\text { Head } \\
\text { Circum- } \\
\text { ference } \\
\text { (cm.) }\end{array}$ & \\
\hline 1 & S.J. & 15 & Listeria & 7 & 250 & 2 & 8 & 5 & 47 & $\begin{array}{l}\text { Attends ordinary school; one } \\
\text { revision of shunt }\end{array}$ \\
\hline $\begin{array}{l}2 \\
3 \\
4 \\
5\end{array}$ & $\begin{array}{l}\text { S.S. } \\
\text { S.D. } \\
\text { D.M. } \\
\text { C.P. }\end{array}$ & $\begin{array}{r}21 \\
10 \\
3 \\
21\end{array}$ & $\begin{array}{l}\text { Meningococcus } \\
\text { Meningococcus } \\
\text { Esch. coli } \\
\text { Pneumococcus }\end{array}$ & $\begin{array}{r}8 \\
12 \\
8 \\
8\end{array}$ & $\begin{array}{l}? \\
400+ \\
220 \\
\text { 'High' }\end{array}$ & $\begin{array}{l}3 \\
3 \\
3 \\
3\end{array}$ & $\begin{array}{r}8 \\
34 \\
11 \\
10\end{array}$ & $\begin{array}{l}5 \\
4 \\
3 \\
3\end{array}$ & $\begin{array}{l}51 \\
54 \cdot 5 \\
49 \cdot 4 \\
50 \cdot 8\end{array}$ & $\begin{array}{l}\text { Ordinary school } \\
\text { Fig. 2: revision of shunt } \\
\text { Revision of shunt } \\
\text { Shunt removed at } 1 \text { year }\end{array}$ \\
\hline $\begin{array}{l}6 \\
7\end{array}$ & $\begin{array}{l}\text { A.W. } \\
\text { L.C. }\end{array}$ & $\begin{array}{l}6 \\
7\end{array}$ & $\begin{array}{l}\text { Proteus } \\
\text { Staph. albus }\end{array}$ & $\begin{array}{r}5 \\
13\end{array}$ & $\begin{array}{l}400+ \\
260\end{array}$ & $\begin{array}{l}3 \\
3\end{array}$ & $\begin{array}{l}10 \\
14\end{array}$ & $\begin{array}{l}2 \\
1\end{array}$ & $\begin{array}{l}53 \\
46\end{array}$ & Had 3 'revisions' \\
\hline
\end{tabular}




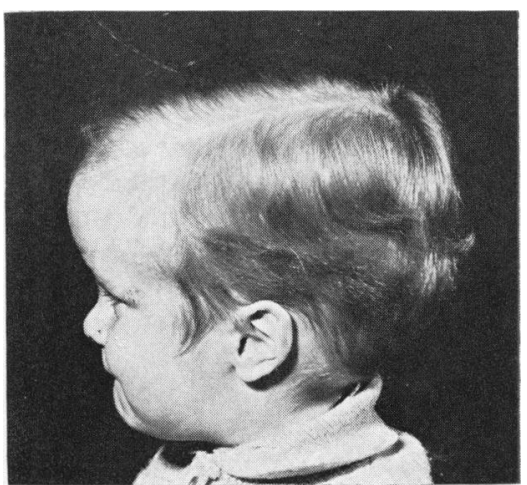

FIG. 3.- $(A . W .$, Table V $)$. Child with persistently large head but of normal intelligence. No sequelae.

facilitated the operative procedure. Nevertheless, revision of the ventriculo-caval shunt became necessary in 4 children, due to thrombosis of the jugular vein, and in another (C.P.) the whole system had to be removed at 1 year of age, because of ulceration of the skin over the valve itself. Fortunately this infant apparently no longer required the shunt and made good progress during the next two years.

At the time of their last examination only 2 had an abnormally large head (S.D., and A.W. (see Fig. 3)),

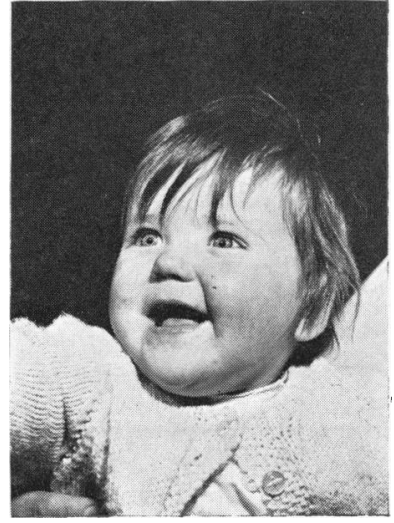

Fig. 5.-Same child as Fig. 4 after recovery.

the head circumference of another was at the 90th percentile (C.P.). The external appearance and head circumference measurement of the other 4 were normal (Fig. 4 and 5). One child (S.S.) had a concomitant squint. Apart from these there were no abnormal features.

Over-all results. Table VI gives the over-all results in our 19 cases. In the context of the type of patients we are dealing with these can be considered

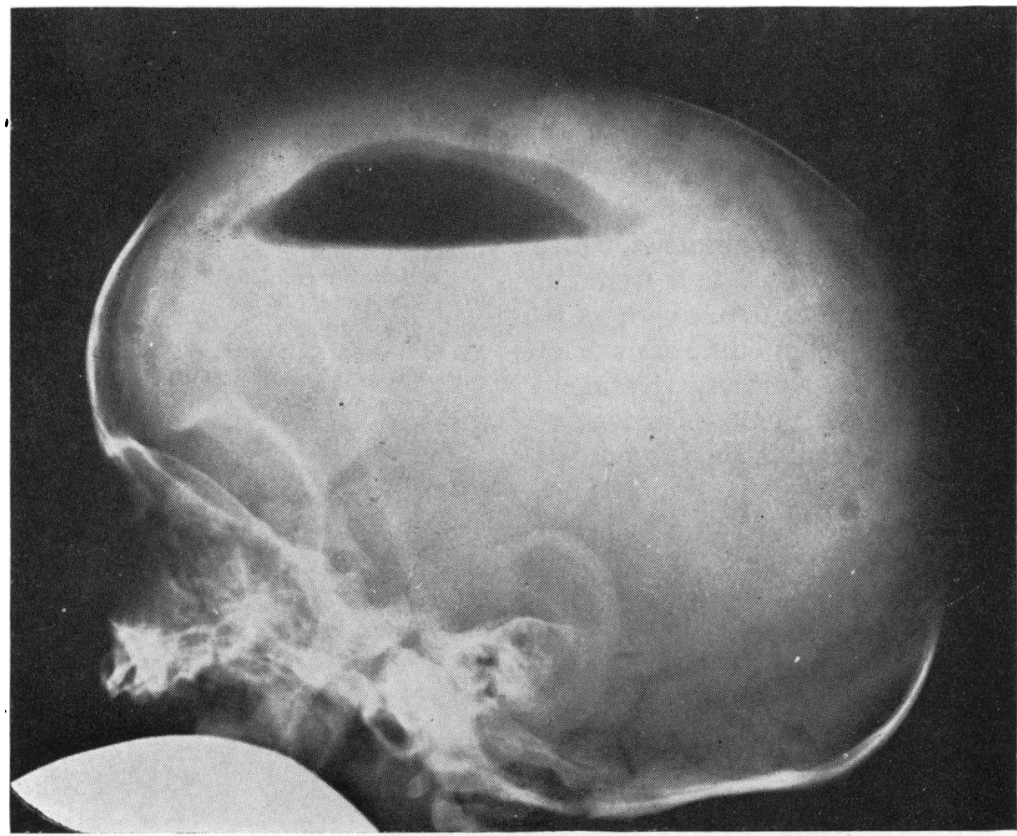

Fig. 4.-(L.C., Table V). Ventriculogram in a baby before operation. 
TABLE VI

Summary of Results of Cases of Post-meningitic Hydrocephalus, 1958-1964

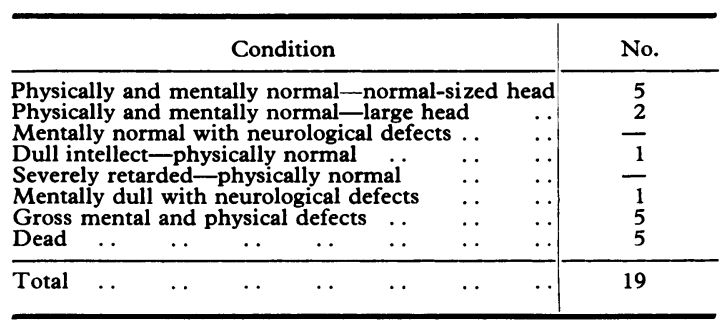

satisfactory, though there are 5 among the 14 survivors who are profoundly handicapped.

The essential feature to emphasize is that one must give the benefit of the doubt to the patient every time one has to make a decision as to operation, because it is impossible to give a precise prognosis in an individual case. In particular, surgical relief of the hydrocephalus must not be withheld because the ventricular dilatation is extreme. Of our 14 survivors, 13 had extreme degree of hydrocephalus, yet 6 of them have no sequelae whatever. A more timid approach might well have led to an increased mortality and to much avoidable physical and mental sequelae in the survivors.

The results of surgical treatment of hydrocephalus resulting from neonatal meningitis are nevertheless inferior to those obtained in congenital hydrocephalus unassociated with meningomyelocele (Lorber, to be published). There may be several reasons for this, but the most important is the brain damage resulting directly from the bacterial infection at a most crucial stage of cerebral development.

It is now apparent from the results obtained in the treatment of new cases of neonatal meningitis, which was achieved in our maternity unit, and from the salvage among those who came to us with postmeningitic hydrocephalus, that with little or no delay in diagnosis and with accurate antibiotic treatment, followed by surgery if necessary, the prognosis of neonatal meningitis may be regarded somewhat less gravely than in the past.

\section{Summary}

The incidence of meningitis in the first few weeks of life is higher than in any comparable period of life, even if cases associated with spina bifida cystica are excluded. The gravity of the prognosis even since the introduction of many powerful antibiotic drugs has been frequently emphasized.

Among our 7 cases which occurred in a maternity unit, 5 eventually made a complete recovery.

In a group of 19 infants who developed postmeningitic hydrocephalus and were referred either with still active meningitis or the post-meningitic state, only 1 infant could not be treated by a ventriculo-caval shunt. This infant and 4 others died later. Of the 14 survivors, 7 recovered without sequelae, in spite of extreme hydrocephalus which was demonstrated by air studies before operation. The degree of hydrocephalus, no matter how severe, is no contraindication to operation.

We wish to thank all our many colleagues who kindly referred these interesting and difficult cases to us for study and treatment.

\section{REFERENCES}

Bruce, A. M., and Lorber, J. (1964). Is antibiotic prophylaxis necessary in spina bifida? Develop. Med. Chila Neurol., 6, 18.

Bush, R. T. (1964). Purulent neonatal meningitis. N.Z. med. F., 63, 137.

Dyggve, H. (1962). Prognosis in meningitis neonatorum. Acta paediat. (Uppsala), 51, 303.

Groover, R. V., Sutherland, J. M., and Landing: B. H. (1961). Purulent meningitis of newborn infants. New Engl. F. Med., 264, 1115.

Haggerty, R. J., and Ziai, M. (1964). Acute bacterial meningitis. Advanc. Pediat., 13, 129.

Lorber, J. (1961). Systematic ventriculographic studies in infants born with meningomyelocele and encephalocele. The incidence and development of hydrocephalus. Arch. Dis. Childh., 36, 381 .

, and Bruce, A. M. (1963). Prospective controlled studies in bacterial 'meningitis' in spina bifida cystica. Develop. Med. Child Neurol., 5, 146.

—, and Grainger, R. R. (1963). Cerebral cavities following ventricular punctures in infants. Clin. Radiol., 14, 98.

, and Segall, L. M. (1962). Bacterial meningitis in spina bifida cystica: a review of 37 cases. Arch. Dis. Childh., 37, 300.

Watson, D. G. (1957). Purulent neonatal meningitis. A study of 45 cases. F. Pediat., 50, 352.

Yu, J. S., and Grauaug, A. (1963). Purulent meningitis in the neonatal period. Arch. Dis. Childh., 38, 391. 